\section{Response of Japanese Privet to Plastic Mulch Applied over Nonspaced Containers}

\author{
Shawn T. Steed ${ }^{1,4}$, Allison Bechtloff ${ }^{2}$, Andrew Koeser ${ }^{3}$, and \\ Tom Yeager ${ }^{2}$
}

AdDITIONAL INDEX wORDs. Ligustrum japonicum, woody plant production, pot-topot, overhead irrigation

SUMMARY. Mulches have many positive benefits for the production of plants, ranging from weed suppression to water conservation. In this study, a novel method of using plastic film mulch for container-grown plants was evaluated. Plots of 25 japanese privet (Ligustrum japonicum) in \#1 $(2.5 \mathrm{qt})$ nonspaced containers were wrapped with 1.25-mil white or black plastic mulch over the top and sides of containers. Small plants were planted through the plastic and grown for 22 weeks with overhead irrigation. Water application amount was determined by moisture sensors placed in the substrate of each treatment. Plant growth, dry weights (DWs), weed fresh weights, weeding time, substrate electrical conductivity (EC), substrate temperature, total water applied, and mulch costs were determined. Black plastic (BP) and white plastic (WP) mulch reduced water applied by $82 \%$ and $91 \%$, respectively, compared with the nontreated control (NT). Nontreated control plants grew faster and had greater DW at the end of the experiment. Mulched containers had fewer weeds and required less labor to remove weeds than the NT treatment. Substrate EC level was greater in BP and WP treatments than for the NT after 20 weeks, and plastic mulch did not result in different substrate temperatures. Plastic mulch added $\$ 4.94 / 1000$ containers $(\$ 2.24$ input cost and $\$ 2.70$ removal cost) to production costs, not including disposal costs. This novel method of mulching nonspaced plants reduced irrigation water, herbicide applications, and weeding labor, but probably added $2-3$ weeks to finish time.

$\mathrm{F}$ lorida is one of the leading states for the commercial production of ornamental horticulture in the United States, producing $\$ 1.8$ billion in crop value per year (U.S. Department of Agriculture, 2015). About $46 \%$ of the production area is used for container production (Hodges et al., 2016). In a survey of Florida nurseries, $76 \%$ of growers produced plants in containers, which represented $86 \%$ of all products sold (Hodges, 2011). In the United States, $65 \%$ of

Thanks to Mosaic Co. Foundation for funding this research and UF/IFAS Statistical Consulting, James Colee, for his assistance with statistical analysis of data.

We would also like to thank Julie Schelb and Drew McLean for their assistance with field work related to this research.

This research was presented at the Annual Meeting of the Florida State Horticultural Society, which was held 4-6 June 2017, in Tampa, FL.

${ }^{1}$ Institute of Food and Agricultural Sciences Extension, University of Florida, Hillsborough County, Seffner, FL 33584

${ }^{2}$ Department of Environmental Horticulture, Institute of Food and Agricultural Sciences, University of Florida, 1545 Fifield Hall, Gainesville, FL 32611

${ }^{3}$ Department of Environmental Horticulture, Center for Landscape Conservation and Ecology, University of Florida Gulf Coast Research and Education Center, 14625 County Road 672, Wimauma, FL 33598

${ }^{4}$ Corresponding author. E-mail: ststeed@ufl.edu.

https://doi.org/10.21273/HORTTECH03865-17 ornamental plants sold were grown in containers. Container production is resource intensive (hand labor, fertilizer, herbicide, etc.) and commonly occurs with overhead irrigation that inefficiently applies large volumes of water (Yeager et al., 2010). Although inefficient with regard to plant water use, overhead irrigation is the least expensive and most flexible method of applying water to container crops because spacing configurations change frequently as plants grow in size or are sold. The population of Florida is estimated to increase by 3 million residents by 2025 (University of Florida, 2017). Population growth in Florida will intensify the demand for water in the future. As water becomes more limited because of increased demand and/or periodic drought, container growers may need to justify their use of water.

Ornamental plants have been grown in a multipot box system with a significant reduction of inputs (water and energy) and increased growth parameters (Irmak et al., 2004). This system captures irrigation and rain water into an irrigation reservoir and shields the external sides of containers from solar radiation. However, the multipot box system does not address other factors such as the lack of weed control, the lack of ability to use existing nursery infrastructure, and the possibly prohibitive cost for large-scale adoption. A similar method could be used, without the reservoir, using a plastic mulch system. A plastic mulch system could improve favorably on some of the aforementioned limitations.

Horticultural crops, such as cucumber (Cucumis satious), eggplant (Solanum melongena), melon (Cucumis melo), pepper (Capsicum annuum), potato (Solanum tuberosum), radish (Raphanus raphanistrum ssp. sativus), squash (Cucurbita pepo), and tomato (Solanum lycopersicum), have benefited from plastic mulch in field production, through water and fertilizer savings, yield increases, earlier fruiting, weed reductions, improved fruit quality, and soil temperature modulation (Lamont, 2005; Locascio et al., 1985; Ramakrishna et al., 2006; Ruidisch et al., 2013; Zhao et al., 2012). We believed

\begin{tabular}{llll}
\hline $\begin{array}{l}\text { Units } \\
\text { To convert U.S. to SI, } \\
\text { multiply by }\end{array}$ & U.S. unit & SI unit & $\begin{array}{l}\text { To convert SI to U.S., } \\
\text { multiply by }\end{array}$ \\
\hline 29.5735 & $\mathrm{fl} \mathrm{oz}$ & $\mathrm{mL}$ & 0.0338 \\
0.3048 & $\mathrm{ft}$ & $\mathrm{m}$ & 3.2808 \\
0.0929 & $\mathrm{ft}^{2}$ & $\mathrm{~m}^{2}$ & 10.7639 \\
3.7854 & gal & $\mathrm{L}$ & 0.2642 \\
2.54 & inch(es) & $\mathrm{cm}^{2}$ & 0.3937 \\
6.4516 & $\mathrm{inch}{ }^{2}$ & $\mathrm{~cm}^{2}$ & 0.1550 \\
0.4536 & $\mathrm{lb}$ & $\mathrm{kg}$ & 2.2046 \\
1.1209 & $\mathrm{lb} / \mathrm{acre}$ & $\mathrm{kg} \cdot \mathrm{ha}^{-1}$ & 0.8922 \\
1 & $\mathrm{meq} / \mathrm{L}$ & $\mathrm{mmol} \cdot \mathrm{L}^{-1}$ & 1 \\
0.0254 & $\mathrm{mil}$ & $\mathrm{mm}$ & 39.3701 \\
1 & $\mathrm{mmho} / \mathrm{cm}$ & $\mathrm{dS} \cdot \mathrm{m}^{-1}$ & 1 \\
28.3495 & $\mathrm{oz}$ & $\mathrm{g}$ & 0.0353 \\
6.8948 & $\mathrm{psi}$ & $\mathrm{kPa}$ & 0.1450 \\
0.9464 & $\mathrm{qt}$ & $\mathrm{L}$ & 1.0567 \\
0.9072 & ton $(\mathrm{s})$ & $\mathrm{Mg}$ & 1.1023 \\
0.7646 & yard & $\mathrm{m}^{3}$ & 1.3080 \\
$\left({ }^{\circ} \mathrm{F}-32\right) \div 1.8$ & ${ }^{\circ} \mathrm{F}$ & ${ }^{\circ} \mathrm{C}$ & $\left({ }^{\circ} \mathrm{C} \times 1.8\right)+32$ \\
& & & \\
\hline
\end{tabular}


that by using a novel method of placing low-density polyethylene mulch over the top of nonspaced (container-tight or pot-to-pot) containers during the beginning phase of the production cycle, similar to vegetable field-grown crops, similar benefits might be attained. The effectiveness of mulch in reducing water loss in container production varies by the study. Altland and Lanthier (2007) demonstrated production with a variety of organic and nonorganic mulch types. Hydrangea (Hydrangea macrophylla) grown with overhead irrigation in a primarily bark substrate had similar water demand to nonmulched control plants. Amoroso et al. (2010) similarly reported water loss from 3-L containers was mainly driven by transpiration of giant arborvitae (Thuja plicata) when mulches were used. By contrast, Argo and Biernbaum (1994) showed in subirrigated easter lily (Lilium longiflorum) grown in peat substrates, covering the surface with a plastic evaporation barrier resulted in 35\% fewer irrigation events and $22 \%$ to $50 \%$ reduction in the amount of water applied compared with nonmulched control plants. Lohr and Pearson-Mims (2001) reported a reduction in frequency of irrigation of $34 \%$ with sphagnum moss mulch and a $13 \%$ reduction with pine bark (0.2- to 0.4 -inch particle size) mulch.

We also believed, similar to other studies, that mulching might cause beneficial temperature modulation (Snyder et al., 2015), which might enhance growth, provide beneficial environmental impacts such as reducing fertilizer leaching (Argo and Biernbaum, 1994), and reduce the need for herbicides (Marble et al., 2017). The mulch might also minimize hand labor to remove weeds and pick up containers that blow over. An important consideration in our study and the use of a mulching method is that growers would have to make minimal costly changes to existing overhead irrigation infrastructure, and there would be no need to buy specialized equipment. The goal of our study was to determine if plastic mulch used over nonspaced containers would provide sustainable benefits (economic, environmental, and quality enhancement) to growers without additional production costs.

\section{Materials and methods}

The experiment was a completely randomized design with three treatments and 10 replicates for a total of 30 plots with dimensions of $7 \times 6 \mathrm{ft}$ on black polypropylene groundcover. Treatments were WP mulch, BP mulch, and a nontreated control that did not receive mulch (NT). Each plot contained 25 trade \#l (2.5 qt) black plastic containers (High Performance 075; Haviland Plastic Products Co., Haviland, $\mathrm{OH}$ ) placed together in a diagonal configuration with five rows of five containers each (Fig. 1). Containers were filled with a 45 Florida peat : 55 pine bark ( $2 \mathrm{~cm}$ in size) by volume. Potting substrate was amended with $45 \mathrm{~kg} /$ yard $^{3}$ dolomite and $9 \mathrm{~kg} /$ yard $^{3}$ minor nutrient mix (Harrell's Fertilizer, Lakeland, FL) and dibbled with $23 \mathrm{~g} / \mathrm{yard}^{3}$ of 270 -d, $15 \mathrm{~N}-2.6 \mathrm{P}-10 \mathrm{~K}$ slow-release fertilizer (Harrell's Fertilizer).

All containers were irrigated to field capacity, and mulched treatments were then wrapped with 1.25-mil (58 inches wide) white-on-black polyethelene plastic mulch (Berry Plastics, Evansville, ID)—randomizing which face (i.e., white or black) was exposed. Plastic mulch treatments were wrapped over the top of all containers and tucked underneath the outer sides and bottom edges of containers. Plots

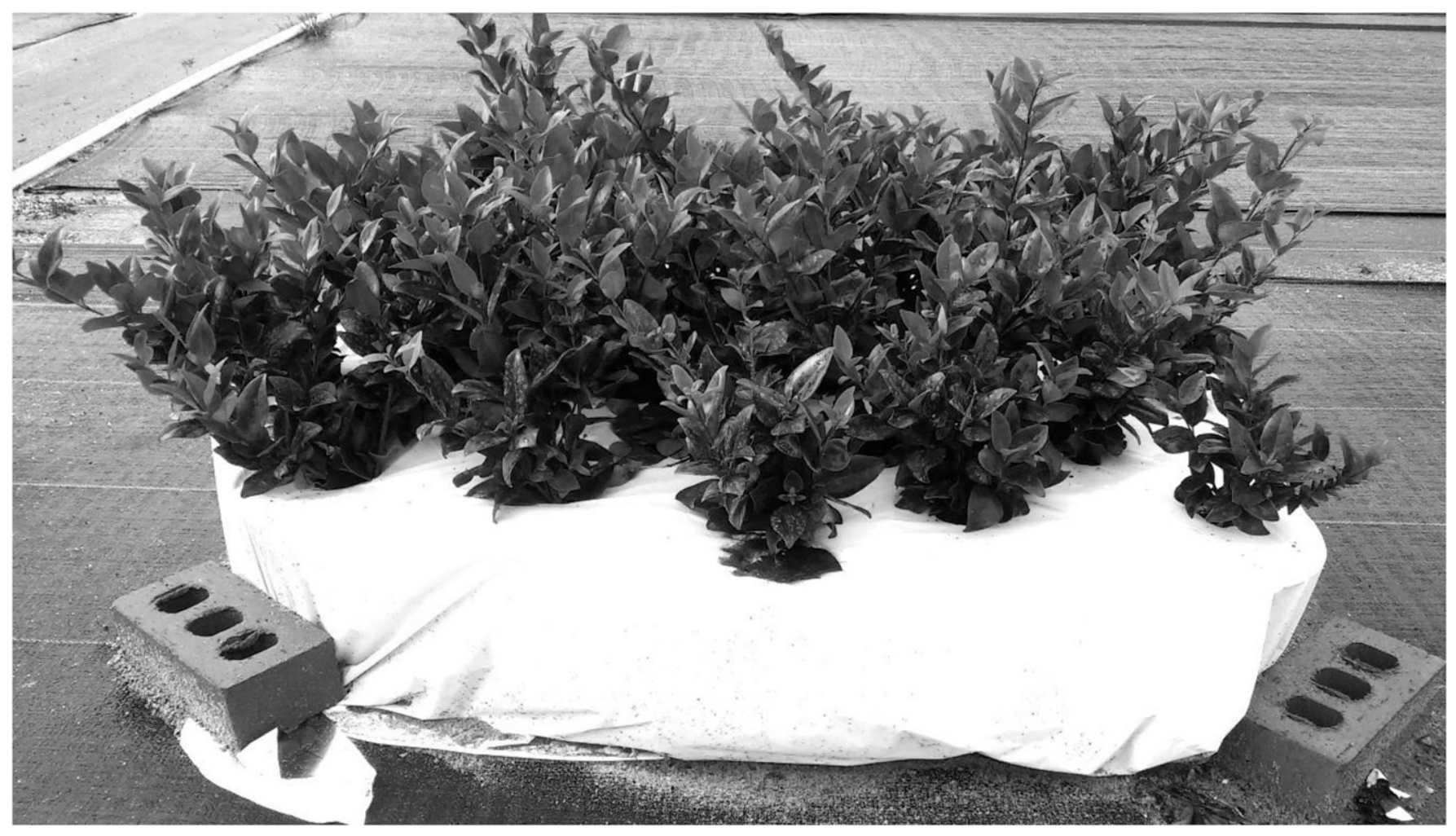

Fig. 1. A plot of 25 nonspaced, container-grown (trade \#1) japanese privet with 1.25-mil (0.0318 mm) white polyethylene mulch treatment covering substrate surface and edges of containers. 
required $55 \times 58$ inches of plastic mulch to wrap the entire group of plants as shown in Fig. 1. Holes were then punched in the center of each container with a metal punch that was $2 \times 2$ inches wide by 3 inches deep. Four-inch-tall rooted cuttings, 40 cells/tray of japanese privet liners (Rosales Nursery, Plant City, FL) were planted one per container through the punched holes. Plants were planted on 31 Mar. 2016.

Each plot was irrigated with four fixed arc nozzles with a $2.4-\mathrm{m}$ radius and $90^{\circ}$ arc (Pro-Spray \#8Q; Hunter Industries, San Marcos, CA) attached to compatible sprayheads (Pro-Spray \#PROS-03; Hunter Industries) on 18 -inch risers with the top of the irrigation spray at an average of 24 inches above the ground surface delivering $\approx 2$ inches $/ \mathrm{h}$ at $40 \mathrm{psi}$ and a distribution uniformity of $84 \%$. Irrigation was separated and water volume was measured by treatment with 1 -inch flow meters (C700; Elster AMCO, Ocala, FL). Irrigation water $\mathrm{pH}$ and EC was 7.7 and $0.433 \mathrm{dS} \cdot \mathrm{m}^{-1}$, respectively. Alkalinity was $2.69 \mathrm{meq} / \mathrm{L}$.

All plots were irrigated for $7 \mathrm{~min}$ twice per day at 0500 and $1400 \mathrm{HR}$ for the first $2 \mathrm{~d}$ after planting. On day 3 and until day 7 , irrigation time was increased to $10 \mathrm{~min}$. On day 4 of the experiment, three data loggers (Hobo Micro Station H21-002; Onset Computer Corp., Bourne, MA), each with three temperature probes with 6-m cables (Smart Temp Sensor 12-bit, STMB-M006; Onset Computer Corp.) were used to measure substrate temperatures. Temperature probes were inserted at a depth of 4 inches below the substrate surface in the center of the container. The center containers were used in each of the treatments for temperature readings for a total of nine sensors (three per treatment). Temperatures were recorded every $10 \mathrm{~min}$ for the duration of the experiment. Temperature data from the 15th day of each month (April to August) were used for analyzing the variance of daily temperature, mean daily temperature, and standard deviation of daily temperature, minimum at $0600 \mathrm{HR}$ and maximum at $1500 \mathrm{HR}$.

Substrate moisture was monitored with sensors (SM300; Delta-T Devices, Cambridge, UK) calibrated for the container substrate used (Delta-T Devices, 2010) and placed at a $45^{\circ}$ angle in the center of the container below the planted liner. The bottom of the plastic probe above the metal prongs was about $1 / 2$ inch below the substrate surface. One probe per treatment was placed in the center of the experiment and controlled irrigation using a data logger/controller (GP2 Controller; Delta-T Devices). Seven days after planting, initial low- and high-moisturesetting thresholds were set to $15 \%$ and $31 \%$ volumetric water content. On day 12, the lower threshold of moisture setting was increased to $25 \%$ and the upper range was reduced to $30 \%$. All containers were initially irrigated to capacity and then irrigated by controller for the remainder of the experiment.

EC of the substrate was measured using a $100-\mathrm{mL}$ pour-through method (Yeager et al., 1983) I h after irrigation was applied. Three outermost containers from the northeast corner of each plot were sampled. Leachate EC was measured in the field with a hand-held meter (AgriMeter model \#AG6/PH; Myron L Co., Carlsbad, CA). The leachate collected from replications 1,5 , and 10 at 20 weeks after planting (WAP) was also used to measure substrate $\mathrm{pH}$ (data not reported) with the same meter.

Plants were lightly pruned once when canopies were overlapping (when plants were $\approx 7-8$ inches wide) to increase branching and uniformity as in a production setting on 24 June, 6 July, or 18 July for NT, BP, and WP, respectively. Plants were pruned to a height and width of 6 inches. Plants were sprayed with $0.232 \mathrm{~mL} /$ gal spinosad (Conserve SC; Dow AgroSciences, Indianapolis, IN) on 21 July and $1.08 \mathrm{lb} /$ acre Bacillus thuringiensis (Dipel Pro DF; Valent USA, Walnut Creek, CA) with a backpack sprayer on 17 Aug. to control olive shootworm (Palpita persimilis).

Plants were harvested on 31 Aug. 2016. Plastic mulch was removed by hand, with two people grabbing the corners, pulling out from beneath containers and pulling upward over the plants. The time required for plastic removal from each plot was recorded. Aboveground biomass from the nine internal (nonboundary) container plants was cut above the first root and placed into paper bags. Roots were then washed from the same plants with a pressure hose over a screen to remove all potting substrate then placed into paper bags. All plant material was dried at $105^{\circ} \mathrm{F}$ for 2 weeks then weighed. Pruning material was not captured for data collection as pruning was viewed as a reset for crop uniformity, and date varied by treatment. This information was captured by plant growth index (GI).

Plant GI data were recorded as a measure of plant growth (square centimeters) and calculated for five plants per treatment as GI $=H \times$ $\left(W_{1} \times W_{2}\right) / 2$, where $H$ is plant height (centimeters), $W_{1}$ is the widest width of the plant (centimeters), and $W_{2}$ is the width perpendicular to widest width (centimeters). Growth index was recorded every 2 weeks beginning 8 WAP. Five containers in a counterclockwise ring around the center plant, starting from the south side, were used for GI data collection.

Plots were hand weeded and the time needed to weed each plot was recorded. At each weeding, weed shoots were cut above the first root, and weed biomass fresh weight was determined per plot, in the field, immediately at harvest time. Hand weeding occurred at $8,12,16$, and 20 WAP.

All data were analyzed using JMP (version 13; SAS institute, Cary, NC). Data were subjected to one-way analysis of variance, and means were compared with Tukey's honest significant difference test at the $\alpha=0.05$ level.

\section{Results and discussion}

IRRIGATION VOLUMES. Irrigation volumes were greatly reduced with the use of plastic mulch. This agrees with previous reports of irrigation savings using mulch on container surfaces (Argo and Biernbaum, 1994; Lohr and Pearson-Mims, 2001). Total water applied for the duration of the experiment was 103,$913 ; 18,912$; and 9813 gal for the NT, BP, and WP treatments, respectively. Water savings equated to $81.8 \%$ for $\mathrm{BP}$ and $90.6 \%$ for WP treatments compared with the NT treatment, as determined by soil moisture sensors. White plastic mulch saved $52 \%$ of the irrigation volume compared with BP possibly because of the reflective nature of white mulch compared with the heat-absorptive property of black mulch. Plastic mulch 
greatly reduced the amount of water evaporated from the substrate surface of the containers. Although evaporation was not measured, when plants were of the same size, irrigation in the control plants was much more frequent. It would, therefore, be assumed that water loss difference from comparisons of treatments would be the amount lost from the surface of the soil. In mulched treatments, irrigation water infiltrated plant holes with the plant acting like a funnel. This might not be the case if plants with a different structural architecture (drooping branches and shedding type architecture) are used with this method. Irrigation water that did not enter plant holes either pooled on the surface of the mulch and evaporated, or drained off sides or into plant holes because of the uneven surface of the mulch. In our study, evaporation from the substrate surface seemed to have a larger impact on the evaporation rate from the container than the amount transpired from leaf area between mulched and nonmulched plants as found in other studies (Amoroso et al., 2010; Altland and Lanthier, 2007).

Plant Growth. Plant growth rate as measured by GI was similar until 8 WAP when a significant difference existed between NT and WP $[P<0.001$ (Fig. 2)]. At this point, there was still no difference in plant size between NT and BP $(P=0.06)$ or WP and BP treatments $(P=0.09)$. At 10,12 , and $16 \mathrm{WAP}$, plants receiving NT were larger than the growth of those with BP or WP, which did not differ from each other (minimum $P=$ 0.12 ). At week 18 , plant size in all three treatments differed (minimum $P=0.008$ ) with NT having the largest plants $\left(621.85 \mathrm{~cm}^{2}\right)$ followed by BP $\left(425.25 \mathrm{~cm}^{2}\right)$ and then WP (326.54 $\mathrm{cm}^{2}$ ). At 20 and $22 \mathrm{WAP}$, no difference of growth occurred between BP and WP treatments. The NT treatment grew to pruning size first, when branches were starting to entangle at 12 WAP, followed by BP at 14 WAP and WP plots at $15 \mathrm{WAP}$. The last week of GI measurements was 22 WAP, when NT plants attained a size that would either be shifted to a larger size or spaced for final sale. At experiment termination, the growth of NT treatment plants were larger than both BP and WP which did not differ from one another as shown in Fig. 3.
About 2-3 weeks in delayed growth separated both mulched treatments from NT.

DW of shoots and roots measured at the end of the experiment (22 WAP) indicated the same reduced growth in mulched treatments (Table 1). Control plants had greater shoot $(22.65 \mathrm{~g})$ and root weight $(5.69 \mathrm{~g})$ compared with BP treatment shoot $[17.20 \mathrm{~g}(P<0.001)]$ and root weight $[4.17 \mathrm{~g}(P<0.001)]$, which did not differ from container plants with WP treatment [shoot DW 15.37 $\mathrm{g}(P=0.28)$ and root DW $4.12 \mathrm{~g}$ $(P=0.98)]$.

Container FerTility. Container ECs did not differ among treatments through 8 WAP and ranged from $0.29 \mathrm{dS} \cdot \mathrm{m}^{-1}$ with the $\mathrm{NT}$ to 0.31 $\mathrm{d} S \cdot \mathrm{m}^{-1}$ of WP (Table 2). The NT treatment EC ranged from a low of $0.19 \mathrm{dS} \cdot \mathrm{m}^{-1}$ at week 20 to a high of $0.41 \mathrm{dS} \cdot \mathrm{m}^{-1}$ at week 12 . Beginning at $12 \mathrm{WAP}$, until the last EC reading at $20 \mathrm{WAP}$, salt levels of WP and BP treatments differed from NT ( $P$ value ranges $<0.001$ ) but did not differ from each other. At each measurement date,
EC levels increased in mulched treatments compared with the control plots such that they were about twice those of the NT plots at 12 WAP, triple at $16 \mathrm{WAP}$, and at $20 \mathrm{WAP}$ the mulched treatments were more than seven times greater than EC of NT at $0.19 \mathrm{dS} \cdot \mathrm{m}^{-1}$ compared with 1.43 $\mathrm{dS} \cdot \mathrm{m}^{-1} \mathrm{BP}$ and $1.31 \mathrm{dS} \cdot \mathrm{m}^{-1}$ for $\mathrm{WP}$ treatment. Fertilizer application amounts were based on the assumption that plants would be growing in the traditional manner with overhead irrigation where fertilizer is constantly being released and leached from the container with each irrigation event. The mulched treatments had greatly reduced irrigation amounts applied, and resultantly, fertilizer did not leach from the containers leading to a higher fertilizer salt build-up over the experimental time frame. This may have delayed growth with the increasing substrate salt levels or potentially a fall in $\mathrm{pH}$ (data not shown) in the substrate because of a large reduction in irrigation water applied to mulched treatments. It is speculated that plants grown with plastic

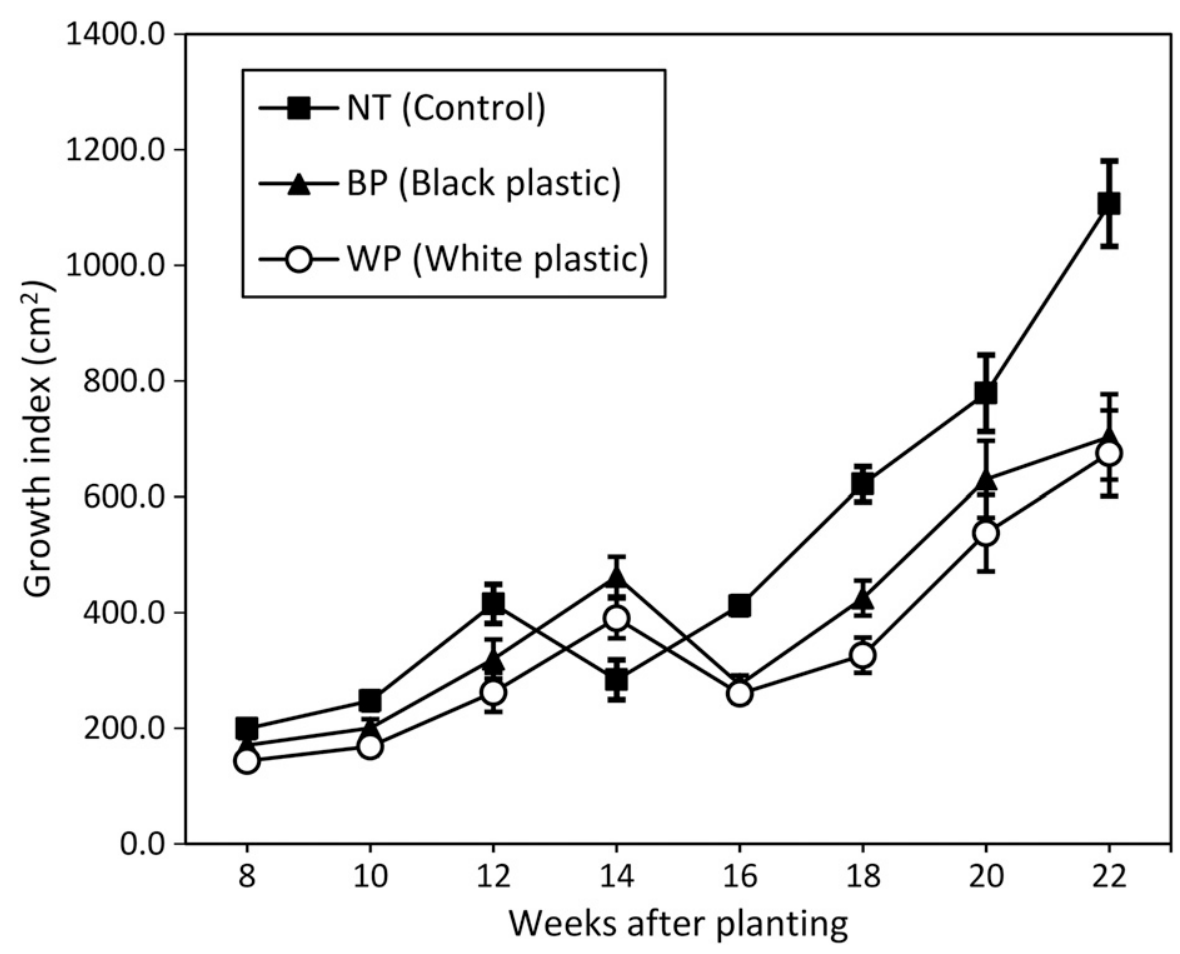

Fig. 2. A comparison of nonspaced, container-grown japanese privet growth index (GI) means of black plastic mulch, white plastic mulch, and control treatments over 22 weeks after planting, grown with overhead irrigation. Where GI $=H \times$ $\left(W_{1} \times W_{2}\right) / 2$, where $H$ is the plant height, $W_{1}$ is the widest width of the plant, and $W_{2}$ is the width perpendicular to the widest width. Error bars are \pm means comparisons using Tukey's honest significant difference test at $\alpha=0.05(n=150)$; $1 \mathrm{~cm}^{2}=0.1550$ inch $^{2}$. 


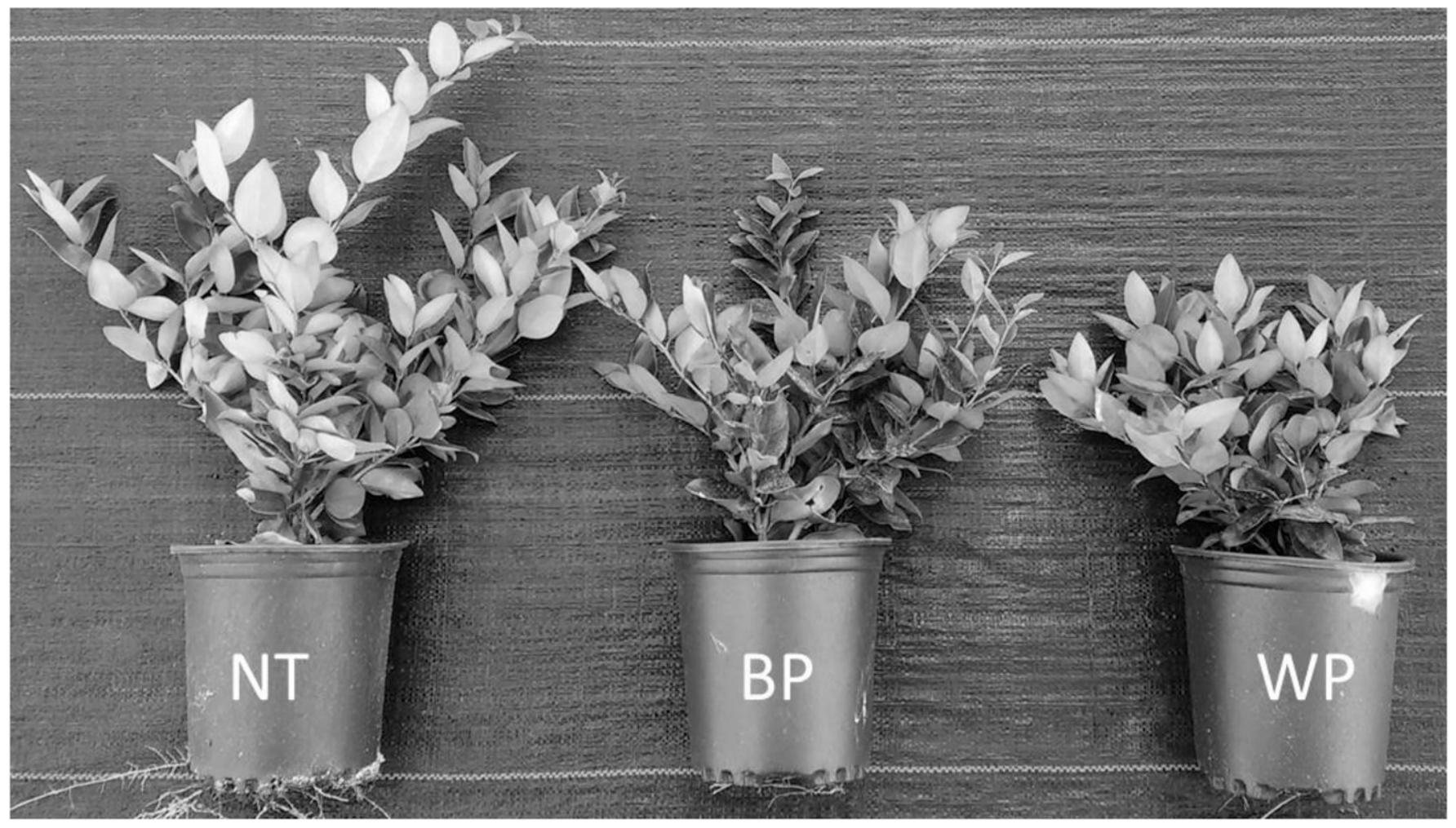

Fig. 3. A sample of nonspaced container \#1 japanese privet, 22 weeks after planting as affected by $1.25-\mathrm{mil}(0.0318 \mathrm{~mm})$ plastic mulch covered bed treatments: $\mathrm{NT}=$ nontreated control; BP = black plastic mulch; WP = white plastic mulch. Line spacing in background is 12 inches $(30.5 \mathrm{~cm})$.

Table 1. Effects of wrapping the surface and edges of a plot of 25 nonspaced container-grown japanese privet with $1.25-\mathrm{mil}$ $(0.0318 \mathrm{~mm})$ plastic mulch on the root and shoot dry-weight biomass per plant grown for 22 weeks with overhead irrigation $(n=270)$.

\begin{tabular}{lcc}
\hline & \multicolumn{2}{c}{ Dry wt $(\mathrm{g} / \text { plant })^{\mathrm{z}}$} \\
\cline { 2 - 3 } Treatment & Shoot & Root \\
\hline Black plastic & $17.20 \mathrm{~b}^{\mathrm{y}}$ & $4.17 \mathrm{~b}$ \\
White plastic & $15.37 \mathrm{~b}$ & $4.12 \mathrm{~b}$ \\
Control & $22.65 \mathrm{a}$ & $5.69 \mathrm{a}$ \\
Significance & $* * *$ & $* * *$ \\
\hline
\end{tabular}

${ }^{\mathrm{z}} 1 \mathrm{~g}=0.0353 \mathrm{oz}$.

${ }^{y}$ Means with the same letters within a column are not significantly different at $P=0.05$ (Tukey's honest significant difference test).

Ns, ${ }^{\star},{ }^{* *},{ }^{* \star}$ Nonsignificant or significant $F$ test at $P \leq$ $0.05,0.01$, or 0.001 level, respectively.

mulch might have fertilizer application levels reduced $50 \%$, or other fertilization methods should be used to lower fertilizer levels in the substrate to prevent season-long increases in salt levels. Another method might be to apply a low rate of a quick-release fertilizer or a short-term controlledrelease fertilizer (CRF) combined with a greatly reduced rate of longer term CRF. An additional method could

Table 2. The effects on nonspaced container-grown japanese privet substrate electrical conductivity (EC) levels when treated with $1.25-\mathrm{mil}(0.0318 \mathrm{~mm})$ plastic mulch placed over the surface and sides of the containers, grown with overhead irrigation, by $100-\mathrm{mL}(3.38 \mathrm{fl} \mathrm{oz})$ pour-through method at $8,12,16$, and 20 weeks after planting (WAP) $(n=90)$.

\begin{tabular}{lcccc}
\hline & \multicolumn{4}{c}{$\mathrm{EC}\left(\mathrm{dS} \cdot \mathbf{m}^{-\mathbf{1}}\right)^{\mathrm{z}}$} \\
\cline { 2 - 5 } Treatment & $\mathbf{8 W A P}$ & $\mathbf{1 2} \mathrm{WAP}$ & $\mathbf{1 6} \mathrm{WAP}$ & $\mathbf{2 0}$ WAP \\
\hline Black plastic & $0.30 \mathrm{a}^{\mathrm{y}}$ & $0.76 \mathrm{a}$ & $0.69 \mathrm{a}$ & $1.43 \mathrm{a}$ \\
White plastic & $0.31 \mathrm{a}$ & $0.88 \mathrm{a}$ & $0.67 \mathrm{a}$ & $1.31 \mathrm{a}$ \\
Control & $0.29 \mathrm{a}$ & $0.41 \mathrm{~b}$ & $0.21 \mathrm{~b}$ & $0.19 \mathrm{~b}$ \\
Significance & $\mathrm{NS}$ & $* * *$ & $* * *$ & $* * *$ \\
\hline
\end{tabular}

${ }^{\mathrm{z}} 1 \mathrm{dS} \cdot \mathrm{m}^{-1}=1 \mathrm{mmho} / \mathrm{cm}$.

${ }^{y}$ Means with the same letters within a column are not significantly different at $P=0.05$ (Tukey's honest significant difference test).

NS, ${ }^{*}{ }^{* \star},{ }^{* \star *}$ Nonsignificant or significant $F$ test at $P \leq 0.05,0.01$, or 0.001 level, respectively.

reduce the build-up of fertilizer salts during production, by using a low level of liquid fertilizer shortly after planting combined with a reduced rate of CRF to complete the growth of the plants toward the end of production. Another method might be to incorporate a leaching irrigation event if EC levels became excessive in the containers; however, this would negate some of the water saving potential of the mulch. The pH of mulched substrate (data not shown) also decreased over the experimental period to an unsatisfactory level, with mulched treatments averaging a $\mathrm{pH}$ of 4.74 at $20 \mathrm{WAP}$ and the control plots averaging a $\mathrm{pH}$ of 6.0. Other research showed similar findings, with a reduced $\mathrm{pH}$ (Argo and Biernbaum, 1994) when using a mulched surface on a containergrown plant with a reduction of applied irrigation water. The irrigation water being used was at a $\mathrm{pH}$ of 7.7, and more frequent irrigations to the containers would probably have increased the $\mathrm{pH}$ of the substrate. 
SUbSTRATE TEMPERATURE DATA. Substrate temperature data for each treatment were compared from the 15th day of each month from April to August. The variance of temperatures over $24 \mathrm{~h}$, the mean temperature of $24 \mathrm{~h}$, the standard deviation of temperatures for a 24 -h duration, the minimum temperature taken at $0600 \mathrm{HR}$, and the maximum temperature taken at $1500 \mathrm{HR}$, all yielded no differences among treatments. The lack of difference was surprising and might be explained partly because of the irrigation being supplied by demand to plots when water status was low. More frequent irrigation events usually occurred during the hotter parts of the day in NT treatments and may have affected substrate temperatures, especially in control plots with irrigation running three to six times per day providing a cooling effect periodically throughout the day (Fig. 4). The lack of significance of mulch modifying the substrate temperature as found in other studies (Snyder et al., 2015) might be partly explained by the insulating effects of placing nonspaced containers surrounding the center container where probes were placed. Variations in the substrate moisture status below the mulch, the air temperature above the mulch, and the thickness of the air layer below the mulch as described by Liakatas et al. (1986) may have also caused fluctuations in substrate temperature in mulched plots compared with NT treatments.

WeEDING EFFects. Plastic mulch greatly reduced weed biomass and resulting labor spent to remove weeds (Table 3). In the first weed harvest 8 WAP, weed biomass fresh weight for $\mathrm{BP}$ and WP mulch treatments did not differ $(P=0.83)$ with weights of 20.14 and $2.95 \mathrm{~g} /$ plot, respectively, but significantly differed from the control plots of $132.7 \mathrm{~g}(P=$ 0.002 ). The trend was similar at 12 and 16 WAP harvests with measurements of WP $1.99 \mathrm{~g}, \mathrm{BP} 3.25 \mathrm{~g}$, and the control with $86.82 \mathrm{~g}$ at week 12 and WP $22.6 \mathrm{~g}, \mathrm{BP} 15.23 \mathrm{~g}$, and control with $126.18 \mathrm{~g}$ at 16 WAP harvest. At $20 \mathrm{WAP}$, weed biomass did not differ because of plant canopies shading the surface of the substrate and excluding weeds. Total season-long weed biomass averaged $51.8 \mathrm{~g} /$ plot for plastic mulch treatments compared with $367.52 \mathrm{~g} /$ plot

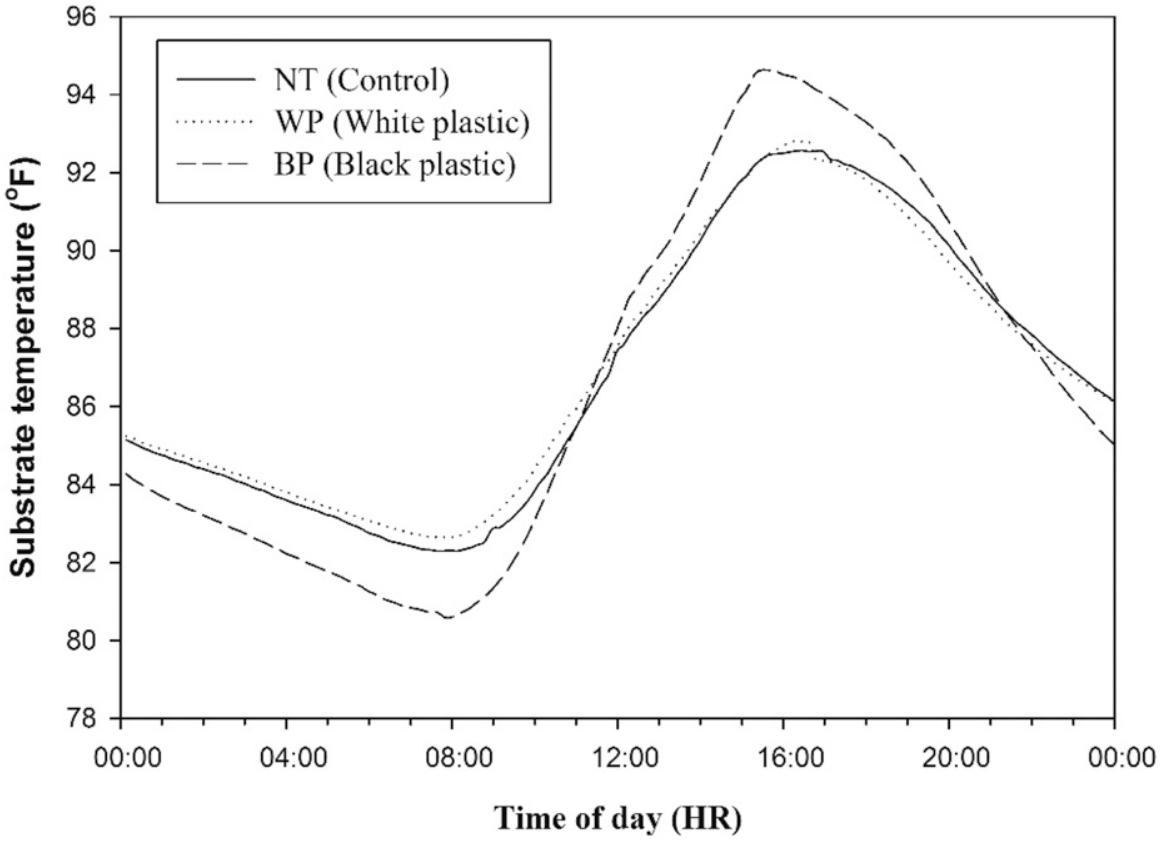

Fig. 4. An example of substrate temperatures on 15 June 2016, taken from a bed of 25 nonspaced \# 1 containers of japanese privet affected by surface and edge applied 1.25 -mil $(0.0318 \mathrm{~mm})$ plastic mulch treatments or no-plastic control with overhead irrigation; $\left({ }^{\circ} \mathrm{F}-32\right) \div 1.8={ }^{\circ} \mathrm{C}$.

for the control treatment for a 7 -fold reduction in season-long weed biomass. Weeding time per plot (Table 3 ) showed a similar trend as weed weight per plot. Weeding times for $\mathrm{BP}$ and WP at 8 WAP did not differ $(P=0.67)$ with times of 26.49 and $5.13 \mathrm{~s} / \mathrm{plot}$, respectively, but did differ from control plot time $123.9 \mathrm{~s} /$ plot $(P=$ $0.001)$. This trend continued in 12 , 16 , and 20 WAP. The total time of weeding for season-long weed control in plots averaged 92 or $3.68 \mathrm{~s} /$ container for the plastic mulch plots and 921.6 or $36.88 \mathrm{~s} /$ container for the NT plots. Plastic mulch contributed to a 10 -fold reduction in labor needed to weed the surface of container-tight container-grown plants for the duration of the growth.

The impact of using mulch is substantial (Table 4). If we assign weeding labor costs at $\$ 10.00 / \mathrm{h}$, weeding 1000 containers would cost $\$ 10.19$ for mulched plants. It would cost \$102.16 for season-long weed management of control plants. Preemergent herbicides were not used in this study and are commonly used by ornamental container plant growers to reduce weed pressure. The use of preemergent herbicides would have controlled weeds to a greater degree on NT plots. Marble et al. (2017) showed that mulch was more effective at reducing hand labor in landscape beds than plots treated with a preemergent herbicide (trifluralin + isoxaben). However, if a different preemergent herbicide was used in their experiment, herbicide plots might have had better results than mulched plots. It was also shown that herbicides did not contribute additional benefits (reductions in handweeding time and frequency) when used in conjunction with mulch, but did reduce hand labor compared with the control (nontreated, nonmulched) plots. In our study, a preemergent herbicide might result in additional reductions in hand labor by reducing weed seed germination in the exposed substrate around the planting hole in the mulched containers. The addition of herbicides adds to the production cost of maintaining weed-free plants. Preemergent herbicides cost $\approx \$ 1.50-\$ 8.00 / 1000 \mathrm{ft}^{2}$ [Florida wholesale prices 2015 , average of 12 common preemergent herbicides $(S$. T. Steed, unpublished data)] and in Florida need to be applied about every 4-6 weeks to maintain weedfree container crops. This would cost around $\$ 7.50-\$ 40.00 / 1000 \mathrm{ft}^{2}$ based on five herbicide applications during a 20 week season, and assuming 4620, 6-inch (trade \#l) containers with a diagonal spacing 
Table 3. The effects of $1.25-\mathrm{mil}(0.0318 \mathrm{~mm})$ plastic mulch applied on the surface and edges of a plot of 25 nonspaced, \#1 containers of japanese privet on weed shoot fresh weight, and hand-weeding time per plot $(n=30)$.

\begin{tabular}{|c|c|c|c|c|c|c|c|c|c|c|}
\hline \multirow[b]{2}{*}{ Treatment } & \multicolumn{2}{|c|}{8 WAP } & \multicolumn{2}{|c|}{12 WAP } & \multicolumn{2}{|c|}{$16 \mathrm{WAP}$} & \multicolumn{2}{|c|}{$20 \mathrm{WAP}$} & \multicolumn{2}{|c|}{ Total } \\
\hline & $\begin{array}{c}\text { Fresh } \\
\text { wt }(g)^{\mathrm{z}}\end{array}$ & $\begin{array}{c}\text { Weeding } \\
\text { time }(s)\end{array}$ & $\begin{array}{c}\text { Fresh } \\
\text { wt }(g)\end{array}$ & $\begin{array}{c}\text { Weeding } \\
\text { time }(s)\end{array}$ & $\begin{array}{c}\text { Fresh } \\
\text { wt }(g)\end{array}$ & $\begin{array}{l}\text { Weeding } \\
\text { time (s) }\end{array}$ & $\begin{array}{c}\text { Fresh } \\
\text { wt }(g)\end{array}$ & $\begin{array}{c}\text { Weeding } \\
\text { time }(s)\end{array}$ & $\begin{array}{c}\text { Fresh } \\
\text { wt }(g)\end{array}$ & $\begin{array}{l}\text { Weeding } \\
\text { time }(s)\end{array}$ \\
\hline Black plastic & $20.14 b^{y}$ & $26.4 \mathrm{~b}$ & $3.25 \mathrm{~b}$ & $9.0 \mathrm{~b}$ & $15.23 \mathrm{~b}$ & $21.9 \mathrm{~b}$ & $12.86 \mathrm{a}$ & $48.2 \mathrm{~b}$ & 51.48 & 105.6 \\
\hline White plastic & $2.95 \mathrm{~b}$ & $5.1 \mathrm{~b}$ & $1.99 \mathrm{~b}$ & $7.7 \mathrm{~b}$ & $22.6 \mathrm{~b}$ & $26.3 \mathrm{~b}$ & $24.58 \mathrm{a}$ & $39.2 \mathrm{~b}$ & 52.12 & 78.4 \\
\hline Control & $132.7 \mathrm{a}$ & $123.9 \mathrm{a}$ & $86.82 \mathrm{a}$ & $264.3 \mathrm{a}$ & $126.18 \mathrm{a}$ & $277.6 \mathrm{a}$ & $21.82 \mathrm{a}$ & $255.8 \mathrm{a}$ & 367.52 & 921.6 \\
\hline Significance & $* * *$ & $* * *$ & $\star * *$ & $* * *$ & $* * *$ & $\star * *$ & NS & $* * *$ & & \\
\hline
\end{tabular}

${ }^{\mathrm{z}} \mathrm{lg}=0.0352 \mathrm{oz}$.

${ }^{y}$ Means with the same letters within a column are not significantly different at $P=0.05$ (Tukey's honest significant difference test).

Ns, ${ }^{*}{ }^{* *},{ }^{* \star}$ Nonsignificant or significant $F$ test at $P \leq 0.05,0.01$, or 0.001 level, respectively.

WAP $=$ weeks after planting.

Table 4. A comparison of production factors of nonspaced \# 1 japanese privet, using $1.25 \mathrm{mil}(0.0318 \mathrm{~mm})$ plastic mulch on the container surface versus standard production.

\begin{tabular}{lccc}
\hline & Mulched containers & Standard production (control) & Savings/(loss) using mulch technique \\
\cline { 2 - 4 } Production factor & \multicolumn{3}{c}{ Cost per 1,000 \#1 containers } \\
\hline Plastic mulch cost & $\$ 2.24$ & $\$ 0.00$ & $(\$ 2.24)$ \\
Mulch removal & $\$ 2.70$ & $\$ 0.00$ & $(\$ 2.70)$ \\
Mulch disposal & $\$ 0.00-\$ 0.03^{\mathrm{z}}$ & $\$ 0.00$ & $(\$ 0.03)-\$ 0.00$ \\
Hand weeding $^{\mathrm{y}}$ & $\$ 10.19$ & 102.16 & $\$ 91.97$ \\
Preemergent herbicide & $\$ 0.00$ & $\$ 1.62-\$ 8.66$ & $\$ 1.62-\$ 8.66$ \\
Pumping costs & $-80 \%$ to $-90 \%$ & $\$ 0.00$ & $80 \%$ to $90 \%$ \\
\hline
\end{tabular}

${ }^{\mathrm{z}}$ Assumes an average U.S. tipping fee of $\$ 48.80 / \mathrm{ton}(\$ 53.793 / \mathrm{Mg})$.

${ }^{y}$ Assumes no preemergent herbicides are used.

arrangement; or a cost of $\$ 1.62-$ $\$ 8.66 / 1000$ containers. It is estimated that a very good preventive herbicide program will only control about $80 \%$ to $90 \%$ (personal experience) of container weeds during the season and would, therefore, also incur additional hand-weeding labor costs to produce the crop. The cost of the plastic mulch used was $\$ 10.34 / 1000 \mathrm{ft}^{2}$ or $\$ 2.24 / 1000$ containers with some additional costs for plastic used to seal the edges. Removal times for 20 plots of plastic mulch averaged 24.35 s or $\$ 2.70 /$ 1000 containers (assuming $\$ 10.00 / \mathrm{h}$ labor rate). Additional expenses would be incurred for disposal (in field burning) or recycling of the mulch. The labor cost for mulch application was not included because of the small plot size with the thought that if performed in a production setting the cost would be minimal. Total additional costs with plastic mulch are about $\$ 4.94 / 1000$ containers and would be similar to the total of season-long herbicide applications. Even with nonspaced containers, a substantial granular preemergent herbicide loss has been demonstrated (Gilliam et al., 1992); however, use of mulch in this manner would greatly reduce the amount of herbicides being used in the environment.

The use of plastic mulch in nonspaced production could have many potential positive benefits to the overall sustainability of container nursery production, namely, reducing water, labor, fertilizer use and leaching/ runoff, and pesticide applications. Further research should look at using this method of plastic mulching in other climactic zones for temperature modifications in the root zone. Additional research could focus on determining the correct water/nutrient ratio and possibly eliminating the reduced growth we observed using the plastic mulch method over nonspaced containers.

\section{Literature cited}

Altland, J. and M. Lanthier. 2007. Influence of container mulches on irrigation and nutrient management. J. Environ. Hort. 25:234-238.

Amoroso, G., P. Frangi, R. Piatti, A. Fini, and F. Ferrini. 2010. Effect of mulching on plant and weed growth, substrate water content, and temperature in containergrown giant arborvitae. Hort Technology 20:957-962.

Argo, W.R. and J.A. Biernbaum. 1994. Irrigation requirements, root-medium
$\mathrm{pH}$, and nutrient concentrations of easter lilies grown in five peat-based media with and without an evaporation barrier. J. Amer. Soc. Hort. Sci. 119:1151-1156.

Delta-T Devices. 2010. User manual for the SM300 soil moisture sensor. SM300-UM1.1. Delta-T Devices, Cambridge, UK.

Gilliam, C.H., D.C. Fare, and A. Beasley. 1992. Nontarget herbicide losses from application of granular Ronstar to container nurseries. J. Environ. Hort. 10:175-176.

Hodges, A. 2011. Production and marketing practices in the Florida nursery industry, 2008. Univ. Florida, Inst. Food Agr. Sci. FE894.

Hodges, A., H. Khachatryan, M. Rahmani, and C. Court. 2016. Economic contributions of the environmental horticulture industry in Florida in 2015. Sponsored project report to Florida Nursery, Growers and Landscape Assn. Univ. Florida, Inst. Food Agr. Sci., Gainesville/Apopka, FL.

Irmak, S., D. Haman, A. Irmak, J. Jones, K. Campbell, and T. Crisman. 2004. Measurement and analyses of growth and stress parameters of Viburnum odoratissimum (Ker-gawl) grown in a multi-pot box system. HortScience 39:1445-1455.

Lamont, W.J. 2005. Plastics: Modifying the microclimate for the production of vegetable crops. HortTechnology 15:477-481. 
Liakatas, A., J.A. Clark, and J.L. Monteith. 1986. Measurements of the heat balance under plastic mulches. Part. I. Radiation balance and soil heat flux. Agr. For. Meteorol. 36:227-239.

Locascio, S.J., J.G.A. Fiskell, D.A. Graetz, and R.D. Hawk. 1985. Nitrogen accumulation by peppers as influenced by mulch and time of fertilizer application. J. Amer. Soc. Hort. Sci. 110:325-328.

Lohr, V. and C.H. Pearson-Mims. 2001. Mulching reduces water use of containerized plants. HortTechnology 11:277278

Marble, S.C., A.K. Koeser, G. Hasing, D. McClean, and A. Chandler. 2017. Efficacy and estimated annual cost of common weed control methods in landscape planting beds. HortTechnolgy 27:199-211.
Ramakrishna, A., H.M. Tam, S.P. Wani, and T.D. Long. 2006. Effect of mulch on soil temperature, moisture, weed infestation and yield of groundnut in northern Vietnam. Field Crops Res. 95:115-125.

Ruidisch, M., S. Bartsch, J. Kettering, B. Huwe, and S. Frei. 2013. The effect of fertilizer best management practices on nitrate leaching in a plastic mulched ridge cultivation system. Agr. Ecosystems and Environ. 169:21-23.

Snyder, K., A. Grant, C. Murray, and B. Wolff. 2015. The effects of plastic mulch systems on soil temperature and moisture in central Ontario. HortTechnology 25:162-170.

U.S. Department of Agriculture. 2015. 2012 census of agriculture: Census of horticulture specialties (2014). Vol. 3, Spec. Studies, Part 3. AC-12-SS-3. U.S. Dept. Agr., Natl. Agr. Stat. Serv., Washington, DC.
University of Florida. 2017. Population studies program. 14 June 2017. <https:// www.bebr.ufl.edu/population>.

Yeager, T.H., J. Million, C. Larsen, and B. Stamps. 2010. Florida nursery best management practices: Past, present, and future. HortTechnology 20:8288

Yeager, T.H., R.D. Wright, and S.J. Donohue. 1983. Comparison of pour through and saturated pine bark extract $\mathrm{N}, \mathrm{P}, \mathrm{K}$, and $\mathrm{pH}$ levels. J. Amer. Soc. Hort. Sci. 108:112-114.

Zhao, H., Y. Xiong, F. Li, R. Wang, S. Qiang, T. Yao, and F. Mo. 2012. Plastic film mulch for half growing-season maximized WUE and yield of potato via moisture-temperature improvement in a semi-arid agroecosystem. Agr. Water Mgt. 104:68-78. 